\title{
The Promise and Pitfalls of Ecosystem Services Classification and Valuation
}

\author{
Stephen Flood, Timothy G. O'Higgins, and Manuel Lago
}

\begin{abstract}
We are currently facing the triple interlocked threats of climate change, unsustainable land use change, and the sixth mass species extinction. This chapter firstly outlines these interlinked threats making the case for urgent action. It then documents the efforts to assign economic and non-economic value to our biodiversity (Ecosystem Services) through environmental and ecological economics, highlighting the fundamental philosophical principles underlining both approaches. This sets up a discussion on the development and potential of Ecosystem Services (ESS) as a discipline in its own right, the challenges of application, and the awareness of, and priority assigned to, ESS by policymakers and the private sector. The chapter closes by outlining specific methodological challenges and recommendations for substantially increasing the level of attention and action needed to protect and enhance our invaluable ecosystems in our age of potential ecological collapse.
\end{abstract}

Elements of this chapter are based on the PhD thesis of Flood, S. (2012), which is available online at: http://mural.maynoothuniversity.ie/4760/

\footnotetext{
S. Flood $(\bowtie)$

MaREI Centre for Energy, Climate and Marine and Renewable Energy, Environmental Research Institute, University College Cork, Cork, Ireland

School of Geography, Environment \& Earth Sciences, Victoria University of Wellington, Wellington, New Zealand

e-mail: stephen.flood@ucc.ie; stephen.flood@vuw.ac.nz
}

T. G. O'Higgins

MaREI Centre for Energy, Climate and Marine and Renewable Energy, Environmental Research Institute, University College Cork, Cork, Ireland

e-mail: tim.ohiggins@ucc.ie

M. Lago

Ecologic Institute, Berlin, Germany

e-mail: manuel.lago@ecologic.eu 


\section{Lessons Learned}

- We have documented the development of ESS, from its foundations in environmental and ecological economics to its evolution into FEGS and CICES classifications and valuation frameworks.

- In doing so we have highlighted the challenges of valuation (including issues of scale, biodiversity awareness or literacy, and polycentric governance), and provided lessons and recommendations going forward for the successful application of ESS.

- Combining a number of different tools and methods can help strengthen assessment

- A persistent gap persists between ESS applications and their ability to provide easily usable information for decision-makers

- ESS can help shine a light on what we will lose if we fail to protect valuable (and indeed invaluable) ecosystems and earth's flora and fauna in general.

\section{Needs to Advance EBM}

- Keep it simple - Decision-makers are interested in simple, easy-to-use decision support tools that are understandable and can be easily incorporated into sciencepolicy processes (Ruckelshaus et al. 2015; IPBES 2019; Dunford et al. 2018). Scientists should note that even basic tools are ample for parameterizing and interpreting data at the early stages of applying Biodiversity and Ecosystem Services (BES) information (Ruckelshaus et al. 2015);

- It's not always about the money - Attributing economic values to biophysical ecosystem service estimates is an important conceptual advance. This ability to follow biophysical estimates though to economic value has allowed decision makers to begin having conversations they did not previously engage with, and lead to new policy outcomes (Dunford et al. 2018; Ruckelshaus et al. 2015; Barton et al. 2018);

- Relate BES change to livelihoods and other wellbeing metrics.

\section{Introduction}

"We are the first generation that has a clear picture of the value of nature and its integral link with human well-being. We are also the last generation that has the opportunity to prevent the collapse of our planet's biodiversity in the face of habitat destruction and climate change." (WWF 2018, p. 10).

The scientific evidence indicates that the Earth's climate is changing (IPCC 2014) and, without taking appropriate and early action, climate change will have severe impacts on many of the planet's species and habitats (Scheffers et al. 2016). The 2006 Stern Review emphasises that the benefits of strong early action on climate change is likely to outweigh the costs, and values the cost of inaction at 5\% of global GDP each year indefinitely (Stern 2006). It is important to note the value of global biodiversity is not fully captured in this percentage and the fact that crossing critical tipping points in our ecosystems, that would lead to extensive and run-away species 
and habitat loss, is also not captured. Yet research into the value of ecosystem services reveals that eco-services contribute more than twice as much to human well-being as global GDP (Costanza et al. 2014) and greater investment into the restoration and protection of the ecosystems and habitats that make those services possible can increase resilience to climate change.

\subsection{Climate and Biodiversity Crises and the Need for Change}

The secretariat of the Convention on Biodiversity considered the interlinkages between climate change adaptation and mitigation and biodiversity in a technical report published in 2009. The report established that biodiversity and climate change are interconnected because climate change effects biodiversity and because changes in biodiversity affects our ability reduce our atmospheric greenhouse gas levels (e.g. our natural carbon sinks) and to adapt to and mitigate against the impacts of climate change (CBD Secretariat 2009). It also highlighted the potential of ecosystem-based adaptation to create co-benefits for climate action and biodiversity conservation.

Furthermore, a recent special report by the Intergovernmental Panel on Climate Change (IPCC) indicates significant impacts to biodiversity and other sectors are set to occur even if we keep climate change to $1.5^{\circ} \mathrm{C}$ over preindustrial levels, which are below business-as-usual global average temperature increases by mid-century (IPCC 2018). Biodiversity is at the forefront of climate change impacts globally. Headline results from the 2018 Living Planet Report, published by the World Wildlife Fund (WWF 2018), reveal that Earth is losing biodiversity at a rate seen only during mass extinctions. The report finds that global losses in populations of vertebrate speciesmammals, fish, birds, amphibians and reptiles-have averaged $60 \%$ between 1970 and 2014. Overexploitation of species, agriculture, land conversion, and climate change are the main drivers of biodiversity decline, with climate change becoming a growing threat (Ibid.).

The 2018 Conference of the Parties to the Convention on Biodiversity and the 2019 report from the Intergovernmental Science-Policy Platform on Biodiversity and Ecosystem Services (IPBES) also echo the findings of the WWF Living Planet report in highlighting the critical role of biodiversity and ecosystems functions and services for human well-being with the IPBES reporting that the health of ecosystems, on which we all and all other species depend, is deteriorating at a rapid rate, and only through 'transformative change' can nature be conserved, restored and used sustainably (CBD Secretariat 2018; IPBES 2019). Transformative change should be understood as a fundamental, system-wide reorganisation across technological, economic and social factors, including paradigms, goals and values (IPBES 2019). It was also recognised that climate change is a major and growing driver of biodiversity loss, and that biodiversity and ecosystem functions and services, significantly contribute to climate change adaptation, mitigation and disaster risk reduction.

The IPCC's (2019) Special Report on Climate Change and Land states with high confidence that increasing impacts on land, ecosystems and biodiversity are 
projected under all greenhouse gas emission scenarios with cascading risks occurring across systems and sectors (IPCC 2019). It also states with high confidence that near-term actions to promote sustainable land management will help reduce land and food-related vulnerabilities, provide both short-term positive economic returns and longer-term benefits for climate change adaptation and mitigation, biodiversity and enhance ecosystem functions and services.

\subsection{Ecological Damage as an Externality}

Traditional neo-classical economic approaches neglect to account for market failures of ecological damage due to absence of markets for many environmental public goods.

The field of environmental economics was established to address these types of market failures or 'externalities' and aims to internalise market externalities through considering and capturing social and environmental costs relating to economic activities (Flood 2012; Tietenberg and Lewis 2007).

There are two requirements for decision-making when it comes to quantifying environmental damages.

The first is to determine one's fundamental philosophical position and, contingent on one's worldview, the second is the need to know the extent to which people are willing-to-pay to prevent damages or the willingness-to-accept compensation for damages suffered (Spash 1997).

The philosophical position assumed by environmental economists is that the net utility from the consequences of an action determines whether the action is right or wrong.

Cost-benefit analysis and its tools, such as the contingent valuation method, assume that individuals are able and willing to consider trade-offs in relation to public goods, i.e. that individuals follow a utilitarian philosophy (Ibid.).

The contingent valuation method involves directly questioning people, in a survey or interview, how much they would be willing to pay for specific environmental services.

It is called "contingent" valuation, because people are asked to state their willingness to pay, contingent on a specific hypothetical scenario and description of the environmental service.

This utilitarian standpoint is the approach from which the majority of socioeconomic impacts associated with ecological damage are approached in the literature (Flood 2012).

This tendency towards the single metric of monetary valuation and the reluctance of the mainstream to consider other numéraires finds its roots in the epistemology of the Enlightenment or Age of Reason (Flood 2012). Enlightenment thinking originates with 17th and eighteenth century European thinkers such as Voltaire, Rousseau, Kant and Hegel, with foundations built upon the theories of Descartes (Van Asselt and Rotmans 2002). In unpacking the field of economic evalution of ecosystem services, the question of substitutability is one that burns at the very core of the 


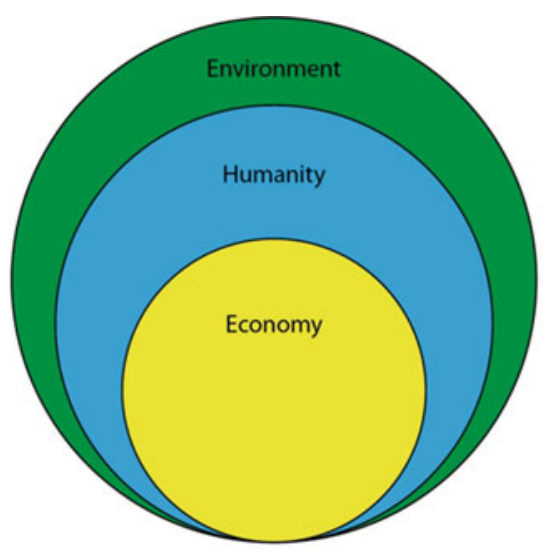

ECOLOGICAL ECONOMICS

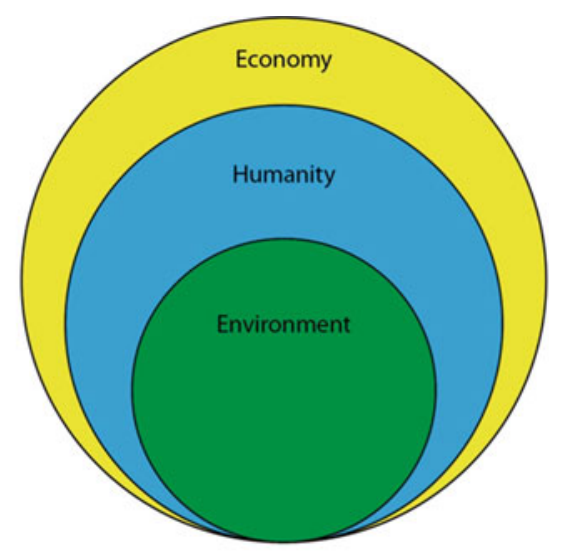

NEO-CLASSICAL ECONOMICS

Fig. 1 Foundations of ecological economics and environmental economics

debate and is intertwined with questions of ethics (Flood 2012). The implicit utilitarian viewpoint of environmental economics, and in particular cost-benefit analysis, precludes the preservationist perspective which focuses on non-human intrinsic values associated with environmental systems (Spash 1997). Most environmental policy is couched in terms of calculating the usefulness to humans of preserving specific environmental goods and services provided by environmental systems. This contrasts with the foundations of ecological economics.

Ecological economics is holistic in its approach and much less anthropocentric than environmental economics. It also tends towards rights-based thinking. Figure 1 displays the fundamental differences between ecological economics and traditional neo-classical economics approaches, in terms of their view of the environment, economy and humanity (Flood 2012). Neo-classical economics tends to view the environment and humanity as embedded within the economy. Ecological economics takes a more holistic approach and considers the economy as a part of humanity living within its environment. Making decisions on a utilitarian basis is considered the most sensible approach by the majority of economists (Spash 1997).

However, we must be careful not obviate the fact that it is the analysis of public policy choices (housing, transport, etc) that also marks the way analytical approaches are designed for environmental protection. If we seek economic efficiency in public policy choices, to ascertain if the investment is worth it or money would be better employed somewhere else, the rationalist would suggest the logic of employing the same approach to inform policy choices for the environment in the absence of alternative decision-making techniques or approaches. Moreover, the challenge is that if we take decisions about the environment outside conventional decision making approaches, we may well end up marginalising environmental decisions and, as a society, be unable to assess where money is best employed. In other words, the risk of the ecological economics approach is that environmental 
decision making may suffer from isolation from other public policy areas, as it is very difficult to consider or mix monetary budget lines with other metrics. It can be argued that looking at environmental choices in isolation will not lead to real-world solutions, and rather they should be considered in the context of a wider public policy debate.

\subsection{Traction: ESS as a Discipline in Its Own Right}

Ecosystem Services (ESS) are benefits humans recognise as obtained from an ecosystem and that support, directly or indirectly, their survival and quality of life (Millennium Ecosystem Assessment 2005). This recognition of the idea of 'natural capital' was first coined in the book Small is Beautiful by E.F Schumacher in the 1970s (Schumacher 1973). The term 'environmental services' was introduced in a 1970 report: The Study of Critical Problems (MIT Press 1970). The services listed in the report included flood control, climate regulation, insect pollination, and fisheries. This concept ESS has continued to develop and expand to include both conservation and socio-economic objectives. Ecosystem goods and ecosystem services were combined by Robert Costanza and his colleagues in the Millennium Ecosystem Assessment (MEA 2005). The Assessment conceptualised the interactions between biodiversity, ecosystem services, human well-being, and drivers of change (Fig. 2).

Changes in drivers that indirectly affect biodiversity, such as population, technology, and lifestyle (upper right corner of Figure), can lead to changes in drivers directly affecting biodiversity, such as the catch of fish or the application of fertilizers (lower right corner). These result in changes to ecosystems and the services they provide (lower left corner), thereby affecting human well-being. These interactions can take place at more than one scale and can cross scales. For example, an international demand for timber may lead to a regional loss of forest cover, which increases flood magnitude along a local stretch of a river. Similarly, the interactions can take place across different time scales. Different strategies and interventions can be applied at many points in this framework to enhance human well-being and conserve ecosystems.

\section{State of the Art ESS Concepts Complexity and Simplicity}

The growing focus on the application of ESS to real world problems has led to a continuous refinement of Ecosystem Services concepts which has reflected the multidisciplinary nature of the research area, at the interface between ecology and society. While the classification system of the Millennium Ecosystem Assessment (MEA), which includes the supporting services, incorporates the full complexity of interactions between ecosystems and human beings, in practice inclusion of 


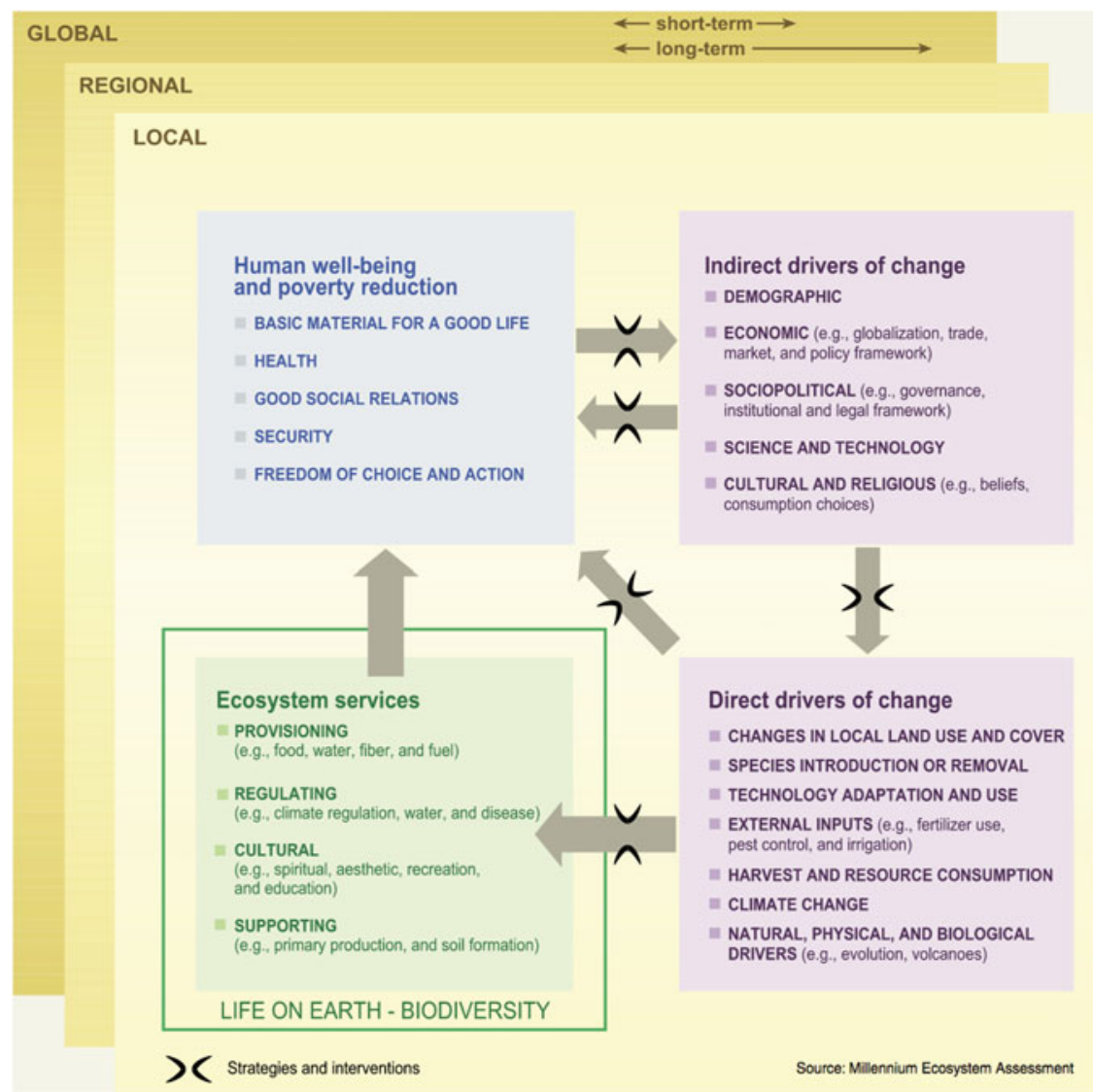

Fig. 2 Millennium ecosystem assessment conceptual framework of interactions between biodiversity, ecosystem services, human well-being, and drivers of change

supporting services in economic analysis can results in double counting. For example, a salmon may result in benefits to human beings, either through commercial harvest (as a provisioning service) or through recreational harvest (as a cultural service). The resulting economic benefits are, the market value (for commercial fisheries) or recreational enjoyment value of the caught salmon (for the recreationally caught fish), less the cost incurred in catching it. If the supporting services such as, habitat provision by freshwater, insect production as a food source for the fish, were also to be valued economically, the human benefits from nature would be double counted. By analogy in valuing a car, we consider the value of the final product but do not separately account for the value of the car manufacturing plant (built capital) and the raw materials (inputs). This practical challenge has been met by development of the Final Ecosystem Goods and Services (FEGS) concept. Final ecosystem services are "components of nature, directly enjoyed, consumed, or used to yield human well-being" (Boyd and Banzhaf 2007). It should also be noted 
Table 1 CICES classification system, with examples of class type

\begin{tabular}{l|l|l|l|l|l}
\hline Section & Division & Group & Class & Code & Class type \\
\hline $\begin{array}{l}\text { Provisioning } \\
\text { (biotic) }\end{array}$ & Biomass & $\begin{array}{l}\text { Reared aquatic } \\
\text { animals for } \\
\text { nutrition, mate- } \\
\text { rials or energy }\end{array}$ & $\begin{array}{l}\text { Animals reared } \\
\text { by in-situ aqua- } \\
\text { culture for } \\
\text { nutritional } \\
\text { purposes }\end{array}$ & 1.1 .4 .3 & Salmon \\
\hline $\begin{array}{l}\text { Regulating } \\
\text { and mainte- } \\
\text { nance } \\
\text { (biotic) }\end{array}$ & $\begin{array}{l}\text { Transformation } \\
\text { of biochemical or } \\
\text { physical inputs to } \\
\text { ecosystems }\end{array}$ & $\begin{array}{l}\text { Mediation of } \\
\text { wastere or toxic } \\
\text { substances of } \\
\text { anthropogenic } \\
\text { origin by living } \\
\text { processes }\end{array}$ & $\begin{array}{l}\text { Bio-remediation } \\
\text { by micro- } \\
\text { organisms, } \\
\text { algae, plants and } \\
\text { animals }\end{array}$ & 2.1 .1 .1 & $\begin{array}{l}\text { In coastal } \\
\text { marine } \\
\text { systems }\end{array}$ \\
\hline $\begin{array}{l}\text { Cultural } \\
\text { (abiotic) }\end{array}$ & $\begin{array}{l}\text { Direct, in-situ } \\
\text { and outdoor } \\
\text { interactions with } \\
\text { natural physical } \\
\text { systems that } \\
\text { requires presence } \\
\text { in the environ- } \\
\text { mental setting }\end{array}$ & $\begin{array}{l}\text { Intellectual and } \\
\text { representative } \\
\text { interactions with } \\
\text { abiotic compo- } \\
\text { nents of the nat- } \\
\text { ural environment }\end{array}$ & $\begin{array}{l}\text { Natural, abiotic } \\
\text { characteristics } \\
\text { of nature that } \\
\text { enable spiritual } \\
\text { symbolic and } \\
\text { other } \\
\text { interactions }\end{array}$ & 6.1 .2 .1 & $\begin{array}{l}\text { Enjoyment } \\
\text { of a land or } \\
\text { sea scape }\end{array}$ \\
\hline
\end{tabular}

that in making just environmental decisions, the consideration of beneficiaries (who benefits) as well as benefits (what type of benefits) is all vital. Applications of the FEGS approaches are described in more detail in this volume by DeWitt et al. (2020) and Yee et al. (2020) and the FEGS concept is essential in the application for the economic valuation of Ecosystem Services and these concepts are commonly employed by ecological economists.

However, the FEGS are only a subset of all the ecosystem services which contribute to human well-being. Internationally, in order to standardise efforts in environmental accounting, considerable efforts have been expended in developing standardised classification systems. Within Europe, the Common International Classification of Ecosystem Services (CICES) is widely adopted, while at the national level with the U.S. the National Ecosystem Services Classification System (NESCS) is emerging (USEPA 2015). These systems attempt to standardise and codify the analysis of ecosystem services, with the aim of informing efforts such as the United Nations System of Environmental-Economic Accounting. The CICES classification system is analogous to the Linnaean biological classification system (phylum, class, genus species) and is comprised of four discrete categories (Table 1).

The CICES classification is the most widely used in Europe, and while developed for the purposes of environmental accounting, it has also been used in efforts to map the supply of ecosystem services (Maes et al. 2015). As with other classification systems, the supporting services of the millennium ecosystem assessment have been dropped and are now incorporated as regulating and maintenance services. CICES also recognises the benefits from non-living components of the environment, as abiotic services. The inclusion of some services which may be seen as intermediate 
rather than final services is one critique of this classification system, and may reflect a disciplinary bias toward ecology in the development of the system.

The focus of ES research, whether encompassing demand-side, human used of FEGS or covering the whole suite of supporting services and final services often depends on the disciplinary background of the researcher. Economists tend to focus only on FEGS and beneficiaries while ecological researchers with an interest in ecosystem services tend to focus on the full range of services, reflecting their interests in the functioning of ecosystems as a whole and the objective of the analysis, whether for simple accounting or to justify actions to maximize specific services.

\subsection{Challenge of Valuation}

While all these systems are designed for the purposes of accounting, the challenges of constructing of an agreed international standard are considerable, and will no doubt continue for many years, in many cases the process of (both monetary and non-monetary) valuation itself presents major challenges. For non-market goods and services there are two major categories of valuation methodologies. Revealed preference methodologies are an indirect methods of estimating the monetary value of an ecosystem service based on how much people spend to access or travel to a site (Silvertown 2015).

Revealed preferences are based on indirect calculations, deriving monetary values from the effects of behavioural change associated with the service (or the lack of it) in real markets (Spangenberg and Settele 2010). They are made up of non-use values (existence values) such as knowing about the existence of a deer population in a region; non-consumptive use values (watching them) and consumptive use values (hunting them) (Ibid.). The two main assessment methods for revealed preference are hedonic pricing and travel cost estimates.

Travel cost is mainly applicable to leisure and holiday activities where travelling is voluntary. In these cases, as the homo economicus is always maximising their utility, and will only be travelling to a particular location if the time spent there provides more utility than saving the cost and abstaining from the visit. (Ibid.). The travel cost is therefore stand-in for the value of what has been enjoyed at the destination. The method gives higher amenity value to a visitor who travels by car than someone who travels on foot or by bicycle even though the former involves the least effort and is the most environmentally damaging (Silvertown 2015).

Knoche and Lupi (2007) calculate the value of the white-tailed deer by assessing the demand for deer hunting via the hunters' travel costs. As a result, the value of 10,000 deer more per county is the result of additional travel expenditures of US $\$ 3.94$ per hunting trip for firearm hunters, and of US\$1.75 per trip for archery hunters.

Hedonic pricing valuations use relationships between land property prices and property characteristics to value changes in the characteristics (Swinton et al. 2007, 
p. 248).They start with the assumption that services/disservices like improved or diminished environmental quality change the willingness to pay for a good associated with them, and this is reflected in the market price (with an implicit assumption of full knowledge and perfect markets), in particular in the housing market. The price change is then a measure of the value of the ecosystem services enjoyed, like a price increase due to the establishment of a nature reserve in the neighbourhood. However, empirical work comparing the changes in individual well-being caused by pollution to housing prices have shown that they do not necessarily reflect the local environmental quality changes (Rehdanz and Maddison 2008; Spangenberg and Settele 2010).

\subsection{Stated Preference-Methodological Advances and Subtleties}

Stated preference approaches simulate a market for ecosystem services through the generation of surveys on hypothetical (policy-driven) changes in the provision of ecosystem services. (TEEB 2012, p. 20). Stated preference methods can be used to estimate non-use and use values of ecosystems. The main types of stated preference techniques are:

1. Contingent valuation method (CV): Uses questionnaires to ask people how much they would be willing to pay to increase or enhance the provision of an ecosystem service, or alternatively, how much they would be willing to accept for its loss or degradation;

2. Choice modeling (CM): Attempts to model the decision process of an individual in a given context (Hanley et al. 1998; Philip and MacMillan 2005). Individuals are faced with two or more alternatives with shared attributes of the services to be valued, but with different levels of attribute (one of the attributes being the money people would have to pay for the service); and

3. Group valuation: Combines stated preference techniques with elements of deliberative processes from political science (Spash 2001; Wilson and Howarth 2002), and are being increasingly used as a way to capture value types that may escape individual based surveys, such as value pluralism, incommensurability, non-human values, or social justice (Spash 2008).

There is a vibrant economic literature on the refinement of stated preference techniques, and these techniques are constantly being defined and developed.

One major drawback of non-market valuation studies, is that (unlike market values) these figures require significant time, effort and expertise to establish, and while real non-market values will vary based on any given unique situation, it is practically unfeasible for reasons of expense and expertise to carry out such studies in every case. As a result, the use of benefits transfer (the practice of taking values from existing studies and applying them at another site) is commonplace. However 
this practice results in uncertainty which can undermine their usefulness in decision making contexts. The potential for big data to contribute to the volume of information on human recreational use patterns is beginning to improve the capacity to tailor economic valuation studies to specific locations (Adamowicz et al. 2011).

\subsection{Splitters and Lumpers: Real World Complexity, Bundling and Its Implications}

In reality ecosystems services generally do not exist in isolation but emerge as a bundle, jointly produced from a range of ecosystem processes and components (Fisher et al. 2009). For example, a healthy river ecosystem provides clean drinking water and salmon and waste remediation services as well as opportunities for active and passive recreational use and the interactions between the ecosystem processes which contribute to these bundled services operate together as a system. Developing quantitative understandings of the ecosystem processes themselves and understanding how these systems respond to human activities may highly complex ecological modelling approaches (see Fulford et al. 2020), yet the joint bundled of benefits to humans is something relatively easily understood intuitively and without deep ecological knowledge. Recognition and communication of the characteristics of joint ecosystem services supply may in some cases be more useful than, providing an exhaustive list of services provided by a given system or developing a mechanistic understanding of how the different ecosystem components interact to produce services.

Carefully developed frameworks and classifications such as the Millennium Ecosystem Assessment (MEA), Final Ecosystem Goods and Services (FEGS), and the Common International Classification of Ecosystem Services (CICES) untangle the complexities of capturing and valuing ESS. However, scholars and practitioners grapple with these frameworks and classifications when applying them on the ground (Harrison et al. 2018).

While Ecosystem Services are intuitively understood, even the youngest school child can understand that "the cow gives us milk" or the "sea gives us fish" or that "a flower is pretty". As illustrated in Table 1, the formal language used to describe ecosystem services is very precise, but not particularly accessible. While anybody can understand the concept of "a beautiful view" this, same concept is perhaps not optimally expressed as "Intellectual and representative interactions with abiotic components of the natural environment". These difficulties with the communication of Ecosystem services have resulted in a suite of different terms being used, for example "natures benefits", "natural capital", "natures' services". 


\subsection{Scale and Polycentric Governance}

While philosophical battles have been won and lost over the ethics, as well as practical and theoretical considerations of valuing nature, these debates over valuation have tended to obscure the broader applicability of ecosystem service concepts to the field of environmental management. Flows of ecosystem services from location to location establish transactional relationships between different jurisdictions. Your country may benefit from the ecosystem services produced in my country. The most obvious current example is that of the Amazon rainforest. The Amazon provides climate regulation services (as well as a wealth of biodiversity) for the entire earth, but is largely under the jurisdiction of Brazil, therefore Brazilian management practices have the potential to increase or reduce the supply of ecosystem services to all of us. This situation sets up a power dynamic between Brazil and the rest of the global community. Systematic considerations of ecosystem service flows and the geographic characteristics of supply and demand can enable the development of institutional arrangements accounting for such natural flows.

\section{The Power of the Word "Biodiversity" to Communicate with the Public}

In light of these issues we propose that an important component of increasing the uptake and application of ESS or BES in everyday decision-making is through mainstreaming into policy as well as the public consciousness. Here, we will concentrate on educating and informing the public consciousness. A good place to start is by looking at the awareness of different populations to the concept of biodiversity, as a foundation for understanding of ES.

A 2015 Eurobarometer captures and presents the attitudes of Europeans towards biodiversity (European Commission 2015). More than half of the 27,718 respondents agree that the European Union (EU) should better inform its citizens about the importance of biodiversity $(61 \%)$, that the EU should ensure that biodiversity concerns are taken into account when planning new infrastructure investments (55\%), and that it should better implement existing nature and biodiversity conservation rules $(55 \%)$ (Ibid.). Furthermore, of the $60 \%$ of respondents who have heard of the term 'biodiversity', only half of them have an understanding of what it means. Those living in western and southern areas of the EU are more likely to have heard of the term 'biodiversity' and know what it means. Two thirds (66\%) of Europeans do not feel informed about the loss of biodiversity, with $22 \%$ saying that they do not feel informed at all (Ibid.).

The Union for Ethical Bio Trade carried out a six-year survey (from 2009 to 2015 ) to determine the levels of knowledge of the term biodiversity from 47,000 consumers in 16 countries across the globe (UEBT 2015). The key findings revealed 
Table 2 Biodiversity awareness around the world (Adapted from UEBT 2015) numbers indicate percentages

\begin{tabular}{|c|c|c|c|}
\hline $\begin{array}{l}\text { Region/ } \\
\text { Country }\end{array}$ & $\begin{array}{l}\text { Have heard of } \\
\text { biodiversity }\end{array}$ & $\begin{array}{l}\text { Correct definition of } \\
\text { biodiversity }\end{array}$ & $\begin{array}{l}\text { With partial definition of } \\
\text { biodiversity }\end{array}$ \\
\hline \multicolumn{4}{|l|}{ Europe } \\
\hline UK & 68 & 26 & 17 \\
\hline Netherlands & 59 & 27 & 16 \\
\hline France & 91 & 34 & 25 \\
\hline Germany & 38 & 18 & 9 \\
\hline Switzerland & 83 & 37 & 18 \\
\hline \multicolumn{4}{|l|}{ Americas } \\
\hline USA & 58 & 22 & 18 \\
\hline Mexico & 90 & 46 & 20 \\
\hline Colombia & 93 & 44 & 18 \\
\hline Ecuador & 82 & 14 & 30 \\
\hline Brazil & 92 & 44 & 19 \\
\hline Peru & 52 & 7 & 37 \\
\hline \multicolumn{4}{|l|}{ Asia } \\
\hline China & 94 & 64 & 22 \\
\hline India & 40 & 1 & 25 \\
\hline South Korea & 73 & 47 & 16 \\
\hline Japan & 62 & 29 & 21 \\
\hline Vietnam & 95 & 36 & 6 \\
\hline
\end{tabular}

that one out of three respondents could provide a current definition of biodiversity. Table 2 provides an overview of the results.

\section{Recommendations}

It has been suggested that combining a number of different tools and methods can help strengthen assessment (Harrison et al. 2018; Barton et al. 2018). Recent reviews point to a persistent gap in the promise of ESS to provide easily usable information for decision-makers (Ruckelshaus et al. 2015). Based on significant field-based experience of application of ESS frameworks and classifications 6 emerging lessons have been identified (Ibid.):

1. Include Biodiversity and Ecosystem Services (BES) information as part of an iterative Science-Policy Process;

2. Keep it simple - no matter how much interdisciplinary scientists think they are over-simplifying biophysical or socio-economic processes, decision-makers typically ask for simpler, easy-to-use and understandable decision support tools that can be readily incorporated into science-policy processes (Ruckelshaus et al. 
2015). Even simple tools are complicated enough for parameterizing and interpreting at early stages of applying BES information;

3. It's not always about the money - having the ability to follow biophysical ecosystem service estimates through to economic values has proven to be an important conceptual advance that has opened many decision makers to discussions they previously did not consider. However, conceptually, considering values of biodiversity for its own sake, in addition to ecosystem services, is completely consistent with an ecosystem services approach;

4. Relate BES change to livelihoods and other wellbeing metrics; and

Furthermore, combining tools and methods can yield significant benefits such as (Dunford et al. 2018):

Individual tools are unlikely to address all the needs of a given context, but a range of approaches can be used to assess different aspects of ES, such as different types of green infrastructure, different groups of services, different geographic scales or time-scales, and different types of value (e.g. biophysical, socio-cultural and monetary).

This chapter has made the case for urgent action to protect our ecological systems (biodiversity) from catastrophic decline. ESS can help shine a light on what we will lose if we fail protect valuable (and indeed invaluable) ecosystems and earth's flora and fauna in general. We have documented the development of ESS, from its foundations in environmental and ecological economics to its evolution into FEGS and CICES classifications and valuation frameworks. In doing so we have highlighted the challenges of valuation (including issues of scale, biodiversity awareness or literacy, and polycentric governance), and provided lessons and recommendations going forward for the successful application of ESS.

\section{References}

Adamowicz, W. L., Naidoo, R., Nelson, E., Polasky, S., \& Zhang, J. (2011). Nature-based tourism and recreation. In P. Kareiva, G. Daily, T. Ricketts, H. Tallis, \& S. Polasky (Eds.), Natural capital: Theory and practice of mapping ecosystem services. New York: Oxford University Press.

Barton, D. N., Kelemen, E., Dick, J., Martin-Lopez, B., Gómez-Baggethun, E., Jacobs, S., Hendriks, C. M. A., et al. (2018). (Dis) integrated valuation - Assessing the information gaps in ecosystem service appraisals for governance support. Ecosystem Services, 29, 529-541.

Boyd, J., \& Banzhaf, S. (2007). What are ecosystem services? The need for standardized environmental accounting units. Ecological Economics, 63(2-3), 616-626. https://doi.org/10.1016/j. ecolecon.2007.01.002.

CBD Secretariat. (2009). Connecting biodiversity and climate change mitigation and adaptation: Report of the Second Ad Hoc technical expert group on biodiversity and climate change. Montreal, Technical Series No. 41, 126 pages. Retrieved April 3, 2019, from https://www. cbd.int/doc/publications/cbd-ts-41-en.pdf. 
CBD Secretariat. (2018). Biodiversity and climate change working Group II. CBD/COP/14/L.23. Retrieved April 3, 2019, from https://www.cbd.int/conferences/2018/insession.

Costanza, R., de Groot, R., Sutton, P., van der Ploeg, S., Anderson, S. J., Kubiszewski, I., Farber, S., \& Turner, R. K. (2014). Changes in the global value of ecosystem services. Global Environmental Change, 26, 152-158.

DeWitt, T. H., Berry, W. J., Canfield, T. J., Fulford, R. S., Harwell, M. C., Hoffman, J. C., Johnston, J. M., Newcomer-Johnson, T. A., Ringold, P. L., Russel, M. J., Sharpe, L. A., \& Yee, S. J. H. (2020). The final ecosystem goods and services (FEGS) approach: A beneficiary-centric method to support. In T. O’Higgins, M. Lago, \& T. H. DeWitt (Eds.), Ecosystem-based management, ecosystem services and aquatic biodiversity: Theory, tools and applications (pp. 127-148). Amsterdam: Springer.

Dunford, R., Harrison, P., Smith, A., Dick, J., Barton, D. N., Martín-López, B., Keleman, E., Jacobs, S., Saarikoski, H., Turkelboom, F., Verheyden, W., Hauck, J., Antunes, P., Aszalós, R., Badea, O., Baró, F., Berry, P., Carvalho, L., Conte, G., Czúcz, B., Garcia Blanco, G., Howard, D., Giuca, R., Gomez-Baggethun, E., Grizzetti, B., Izakovicova, Z., Kopperoinen, L., Langemayer, J., Luque, S., Lapola, D. M., Martinez-Pastur, G., Mukhopadhyay, R., Roy, S. B., Niemelä, J., Norton, L., Ochieng, J., Odee, D., Palomo, I., Pinho, P., Priess, J., Rusch, G., Saarela, S.-R., Santos, R., van der Wal, J. T., Vadineanu, A., Vári, Á., Woods, H., \& Yli-Pelkonen, V. (2018). Integrating methods for ecosystem service assessment: Experiences from real world situations. Ecosystem Services, 29, 499-514.

European Commission. (2015). Attitudes of Europeans towards biodiversity. Special Eurobarometer 436. ISBN: 978-92-79-50788-5.

Fisher, B., Turner, R. K., \& Morling, P. (2009). Defining and classifying ecosystem services for decision making. Ecological Economics, 68(3), 643-653. https://doi.org/10.1016/j.ecolecon. 2008.09.014.

Flood, S. (2012). Climate change and potential economic impacts in Ireland: The case for adaptation. PhD Thesis, Maynooth University, Ireland.

Fulford, R. S., Heymans, S. J. J., \& Wu, W. (2020). Mathematical modelling for ecosystem-based management (EBM) and ecosystem goods and services (EGS) assessment. In T. O'Higgins, M. Lago, \& T. H. DeWitt (Eds.), Ecosystem-based management, ecosystem services and aquatic biodiversity: Theory, tools and applications (pp. 275-290). Amsterdam: Springer.

Hanley, N., MacMillan, D., Wright, R. E., Bullock, C., Simpson, I., Parsisson, D., \& Crabtree, B. (1998). Contingent valuation versus choice experiments: Estimating the benefits of environmentally sensitive areas in Scotland. Journal of Agricultural Economics, 49(1), 1-15. https:// doi.org/10.1111/j.1477-9552.1998.tb01248.x.

Harrison, P. A., Dunford, R., Barton, D. N., Keleman, E., Martín-López, B., Norton, L., Termansen, M., Saarikoski, H., Hendriks, K., Gómez-Baggethun, E., Czúcz, B., García-Llorente, M., Howard, D., Jacobs, S., Karlsen, M., Kopperoinen, L., Madsen, A., Rusch, G., van Eupen, M., Verweij, P., Smith, R., Toumasjukka, D., \& Zuilian, G. (2018). Selecting methods for ecosystem service assessment: A decision tree approach. Ecosystem Services, 29, 481-498.

IPBES. (2019). Summary for policymakers of the global assessment report on biodiversity and ecosystem services of the intergovernmental science-policy platform on biodiversity and ecosystem services. In S. Díaz, J. Settele, E. S. Brondizio, H. T. Ngo, M. Guèze, J. Agard, A. Arneth, P. Balvanera, K. A. Brauman, S. H. M. Butchart, K. M. A. Chan, L. A. Garibaldi, K. Ichii, J. Liu, S. M. Subramanian, G. F. Midgley, P. Miloslavich, Z. Molnár, D. Obura, A. Pfaff, S. Polasky, A. Purvis, J. Razzaque, B. Reyers, R. Roy Chowdhury, Y. J. Shin, I. J. Visseren-Hamakers, K. J. Willis, \& C. N. Zayas (Eds.). Bonn: IPBES Secretariat.

IPCC. (2014). Climate change 2014: Synthesis report. Contribution of Working Groups I, II and III to the Fifth Assessment Report of the Intergovernmental Panel on Climate Change [Core Writing Team, R. K. Pachauri \& L. A. Meyer (Eds.)]. Intergovernmental Panel on Climate Change, Geneva, Switzerland, $151 \mathrm{pp}$.

IPCC. (2018). Global Warming of $1.5^{\circ} \mathrm{C}$ : An IPCC special report on the impacts of global warming of $1.5^{\circ} \mathrm{C}$ above pre-industrial levels and related global greenhouse gas emission pathways, in 
the context of strengthening the global response to the threat of climate change, sustainable development, and efforts to eradicate poverty.

IPCC. (2019). Special report on climate change, desertification, land degradation, sustainable land management, food security, and greenhouse gas fluxes in terrestrial ecosystems. Summary for policymakers approved draft. Retrieved August 29, 2019, from https://www.ipcc.ch/site/assets/ uploads/2019/08/Edited-SPM_Approved_Microsite_FINAL.pdf.

Knoche, S., \& Lupi, F. (2007). Valuing deer hunting ecosystem services from farm landscapes. Ecological Economics, 64(2), 313-320. https://doi.org/10.1016/j.ecolecon.2007.07.023.

Maes, J., Fabrega, N., Zulian, G., Barbosa, A., Vizcaino, P., Ivits, E., Polce, C., Vandecasteele, I., Marí Rivero, I., Guerra, C., Perpiña Castillo, C., Vallecillo, S., Baranzelli, C., Baranco, R., Batista e Silva, F., Jacobs-Crisioni, C., Trombetti, M., \& Lavalle, C. (2015). Mapping and assessment of ecosystems and their services: Trends in ecosystems and ecosystem services in the European Union Between 2000 and 2010. Joint Research Centre-Institute for Environment and Sustainability. Luxembourg Publications Office of the European Union, p. 131.

Millennium Ecosystem Assessment (MEA). (2005). Ecosystems and human well-being: Synthesis. Washington, DC: Island Press.

MIT Press. (1970). Man's impact on the global environment: Assessment and recommendations for action: Study of Critical Environmental Problems (SCEP). ISBN: 10: 0262690276.

Philip, L. J., \& MacMillan, D. C. (2005). Exploring values, context and perceptions in contingent valuation studies: The CV market stall technique and willingness to pay for wildlife conservation. Journal of Environmental Planning and Management, 48(2), 257-274. https://doi.org/10. 1080/0964056042000338172.

Rehdanz, K., \& Maddison, D. (2008). Local environmental quality and life-satisfaction in Germany. Ecological Economics, 64(4), 787-797. https://doi.org/10.1016/j.ecolecon.2007.04.016.

Ruckelshaus, M., McKenzie, E., Tallis, H., Guerry, A., Daily, G., Kareiva, P., Polasky, S., Ricketts, T., Bhagabati, N., Wood, S. A., \& Bernhardt, J. (2015). Notes from the field: Lessons learned from using ecosystem service approaches to inform real-world decisions. Ecological Economics., $115,11-21$.

Scheffers, B. R., et al. (2016). The broad footprint of climate change from genes to biomes to people. Science, 354, 6313. https://doi.org/10.1126/science.aaf7671.

Schumacher, E. F. (1973). Small is beautiful: A study of economics as if people mattered (288 p.). Blonde and Briggs. ISBN: 978-0-06-091630-5.

Silvertown, J. (2015). Have ecosystem services been oversold. Trends in Ecology and Evolution., 30(11). https://doi.org/10.1016/j.tree.2015.08.007.

Spangenberg, J. H., \& Settele, J. (2010). Precisely incorrect? Monetising the value of ecosystem services. Ecological Complexity, 7(3), 327-337. https://doi.org/10.1016/j.ecocom.2010.04.007.

Spash, C. L. (1997). Ethics and environmental attitudes with implications for economic valuation. Journal of Environmental Management, 50, 403-416.

Spash, C. L. (2001). Broadening democracy in environmental policy processes. Environment and Planning C: Government and Policy, 19, 475-481.

Spash, C. L. (2008). How much is that ecosystem in the window? The one with the bio-diverse trail. Environmental Values, 17(2), 259-284. https://doi.org/10.3197/096327108X303882.

Stern, N. (2006). Stern review on the economics of climate change. London: HM Treasury.

Swinton, S. M., Lupi, F., Robertson, P. G., \& Hamilton, S. K. (2007). Ecosystem services and agriculture: Cultivating agricultural ecosystems for diverse benefits. Ecological Economics, 64 (2), 245-252. https://doi.org/10.1016/j.ecolecon.2007.09.020.

TEEB (The Economics of Ecosystems and Biodiversity). (2012). The economics of ecosystems and biodiversity: Ecological and economic foundations (p. 456). London: Routledge. https://doi. org/10.4324/9781849775489.

Tietenberg, T., \& Lewis, L. (2007). Environmental and natural resource economics (5th ed.). London: Pearson Publishing.

UEBT (Union for Ethical Bio Trade). (2015). UEBT biodiversity barometer 2009-2015. 
USEPA (United States Environmental Protection Agency). (2015). National Ecosystem Services Classification System (NESCS): Framework design and policy application. EPA-800-R-15-002. Washington, DC: United States Environmental Protection Agency.

Van Asselt, M. B. A., \& Rotmans, J. (2002). Uncertainty in integrated assessment. Modelling: From positivism to pluralism. Climatic Change, 54, 75-105.

Wilson, M. A., \& Howarth, R. B. (2002). Discourse-based valuation of ecosystem services: Establishing fair outcomes through group deliberation. Ecological Economics, 41(3), 431-443. https://doi.org/10.1016/S0921-8009(02)00092-7.

WWF (World Wildlife Fund). (2018). Living planet report 2018: Aiming higher. In M. Grooten \& R. E. A. Almond (Eds.). Gland: WWF.

Yee, S., Cicchetti, G., DeWitt, T. H., Harwell, M. C., Jackson, S. K., Pryor, M., Rocha, K., Santavy, D. L., Sharpe, L., \& Shumchenia, E. (2020). The ecosystem services gradient: A descriptive model for identifying thresholds of meaningful change. In T. O'Higgins, M. Lago, \& T. H. DeWitt (Eds.), Ecosystem-based management, ecosystem services and aquatic biodiversity: Theory, tools and applications (pp. 291-308). Amsterdam: Springer.

Open Access This chapter is licensed under the terms of the Creative Commons Attribution 4.0 International License (http://creativecommons.org/licenses/by/4.0/), which permits use, sharing, adaptation, distribution and reproduction in any medium or format, as long as you give appropriate credit to the original author(s) and the source, provide a link to the Creative Commons licence and indicate if changes were made.

The images or other third party material in this chapter are included in the chapter's Creative Commons licence, unless indicated otherwise in a credit line to the material. If material is not included in the chapter's Creative Commons licence and your intended use is not permitted by statutory regulation or exceeds the permitted use, you will need to obtain permission directly from the copyright holder. 